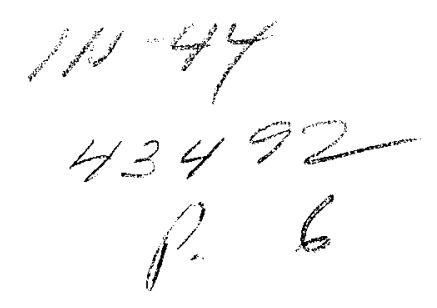

\title{
Design of a GaAs/Ge Solar Array for Unmanned Aerial Vehicles
}

David A. Scheiman

NYMA, Inc.

Engineering Services Division

Brook Park, Ohio

David J. Brinker and David J. Bents

National Aeronautics and Space Administration

Lewis Research Center

Cleveland, Ohio

Anthony J. Colozza

NYMA, Inc.

Engineering Services Division

Brook Park, Ohio

Prepared for the

First World Conference on Photovoltaic Energy Conversion cosponsored by IEEE, PVSEC-Japan, and PVSEC-Europe Waikoloa, Hawaii, December 5-9, 1994
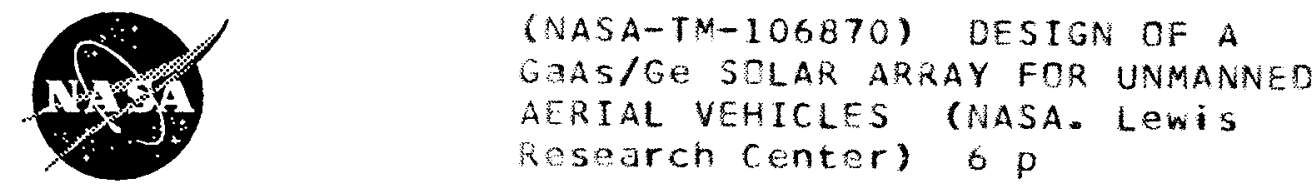


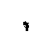




\title{
DESIGN OF A GaAs/Ge SOLAR ARRAY FOR UNMANNED AERIAL VEHICLES
}

\author{
David A. Scheiman, David J. Brinker*, David J. Bents", and Anthony J. Colozza \\ NYMA Setar Inc., Brookpark, Ohio \\ - NASA Lewis Research Center, Cleveland, Ohio
}

\begin{abstract}
Unmanned Aerial Vehicles (UAV) are being proposed for many applications including surveillance, mapping and atmospheric studies. These applications require a lightweight, low speed, medium to long duration airplane. Due to the weight, speed, and altitude constraints imposed on such aircraft, solar array generated electric power is a viable alternative to air-breathing engines. Development of such aircraft is currently being funded under the Environmental Research Aircraft and Sensor Technology (ERAST) program. NASA Lewis Research Center (LeRC) is currently building a Solar Electric Airplane to demonstrate UAV technology. This aircraft utilizes high efficiency Applied Solar Energy Corporation (ASEC) GaAs/Ge space solar cells. The cells have been provided by the Air Force through the ManTech Office. Expected completion of the plane is early 1995, with the airplane currently undergoing flight testing using battery power.
\end{abstract}

\section{BACKGROUND}

ERAST was started by the NASA office of Aeronautics to develop technologies which will enable safe and cost effective environmental research. The potential need for unmanned aerial vehicle's development is expected to grow over the next 10 years and expand into the private sector. Most of the current military applications view the UAV as a disposable vehicle for high risk missions. This effort is expected to enable the U.S. to get a competitive lead in the global market with miniaturized sensors and flight vehicle integration. Other projects being supported by ERAST include the Si solar cell powered RAPTOR/Pathfinder and two internal combustion engine powered planes: RAPTOR/Talon and Perseus.

Possible applications of the UAV include a large number of military and classified surveillance flights where a small aircraft is difficult to detect by radar. These would include flights over such areas as Iraq, Iran, Bosnia, and Haiti. Scientific applications include ozone monitoring, collection of data for weather and global warming studies, investigation of lightning-like flashes observed by shuttle astronauts, and studying the Aurora Borealis [1].
Commercial applications include aerial surveying, geological, and topographical mapping.

Solar cells are viable power source on UAVs for several reasons. As the plane altitude increases and the air density decreases, additional power is required to propel the plane. Solar power density increases with altitude from $80 \mathrm{~mW} / \mathrm{cm}^{2}$ (AM 1.5) on the ground to $136.7 \mathrm{~mW} / \mathrm{cm}^{2}$ in space (AMO), this is shown in Figure 1. A rough calculation for light Intensity in $\mathrm{mW} / \mathrm{cm}^{2}$ as a function of air mass is shown below [2].

$$
\text { Intensity }=1.367 \times 0.7 \text { (air mass) } 0.678 \mathrm{~mW} / \mathrm{cm}^{2}
$$

A second advantage is that, in contrast to an air breathing engine, solar power has no exhaust and therefore does not contaminate the atmosphere nor interfere with any delicate air measuring sensors on the plane. A third advantage is that the solar plane is inherently slower then air breathing planes, which makes them better suited for atmospheric studies. One obvious disadvantage of using solar power is that it is only available in daylight, however battery power could be used to extend flight times.

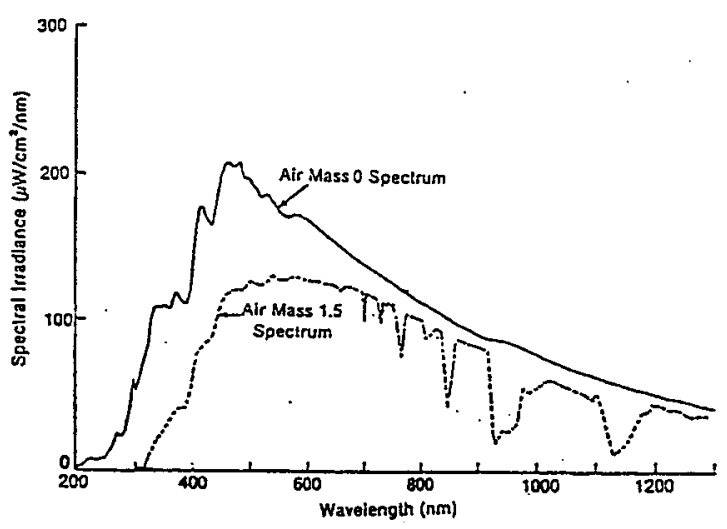

Figure 1: AM1:5 and AMO Spectral Intensity

\section{GaAs/Ge CELLS}

GaAs/Ge cells are now being produced for many space power applications and are readily available. $\mathrm{GaAs} / \mathrm{Ge}$ cells have been shown to be as efficient as GaAs/GaAs 
cells and is considered a mature technology [2]. The GaAs/Ge cells to be used in this project were made by ASEC in 1993 as part of a pilot production run under a ManTech program for Wright Aeronautical Laboratory in Dayton, Ohio. These are Gallium Arsenide cells grown on a inactive $\mathrm{Ge}_{\theta}$ substrate by organometallic vapor phase epitaxy. The Mantech program was set up for a run of 250 cells. These cells are are $6 \mathrm{~cm} . \times 6 \mathrm{~cm}$. in size and are either 3.5 or 4.5 mils thick. The thinness of the cells renders them extremely fragile so handling must be kept to a minimum, all aspects of plane construction are mindful of this.

The cells were measured by ASEC at AMO conditions and sorted by efficiency. Because this program is a developmental program all functional cells were shipped which included cells with mechanical defects, visual defects, and cascaded cells (active $\mathrm{Ge}$ ). The AMO cell efficiencies ranged from $14 \%$ to $19 \%$. The cells were measured at LeRC under AM1.5 illumination. This was chosen over AMO because the plane was designed for low altitude operation. The spectral response data shown in Figure 2 was performed on a $2 \times 2 \mathrm{~cm}$. cell, cut down from a larger cell. The AM1.5 short circuit current calibration was found by integrating the spectral response of the cell over the ASTM standard spectrum. Table I is a summary of the cell. measurements, all cells were measured regardless of their condition. Figure 3 shows a typical IV curve with close to nominal characteristics.

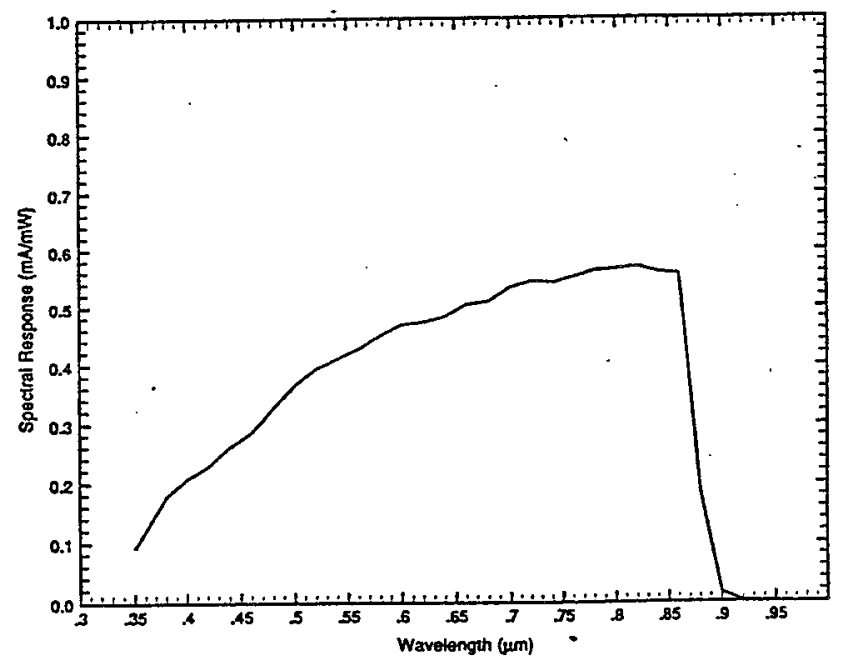

Figure 2: Spectral Response of GaAs/Ge cell

\begin{tabular}{lccc} 
Table I: & \multicolumn{3}{c}{ GaAs/Ge Cell Data at } \\
& mean & sdev & \# 5 (355 cells) \\
\cline { 2 - 4 } $\mathrm{I}_{\text {sc }}$ & $.676 \mathrm{~A}$ & .0136 & 292 \\
$\mathrm{~V}_{\text {oc }}$ & $.997 \mathrm{~V}$ & .0327 & 275 \\
$\mathrm{P}_{\max }$ & $.492 \mathrm{~W}$ & .0475 & 259 \\
$\mathrm{I}_{\max }$ & $.605 \mathrm{~A}$ & .0318 & 294 \\
$\mathrm{~V}_{\max }$ & $.811 \mathrm{~V}$ & .0214 & 257 \\
F & $72.9 \%$ & 5.454 & 250 \\
Eff & $17.77 \% 1.719$ & 258 &
\end{tabular}

The highest cell efficiency measured was $20.43 \%$. The data shows that the current is very consistent. Reverse breakdown characteristics of the cells have been studied by lles et. al. [3] and the results indicate that $\mathrm{GaAs} / \mathrm{Ge}$ is more robust then GaAs/GaAs with respect to the amount of reverse current the cells can handle. These tests have shown that proper screening can eliminate this problem.

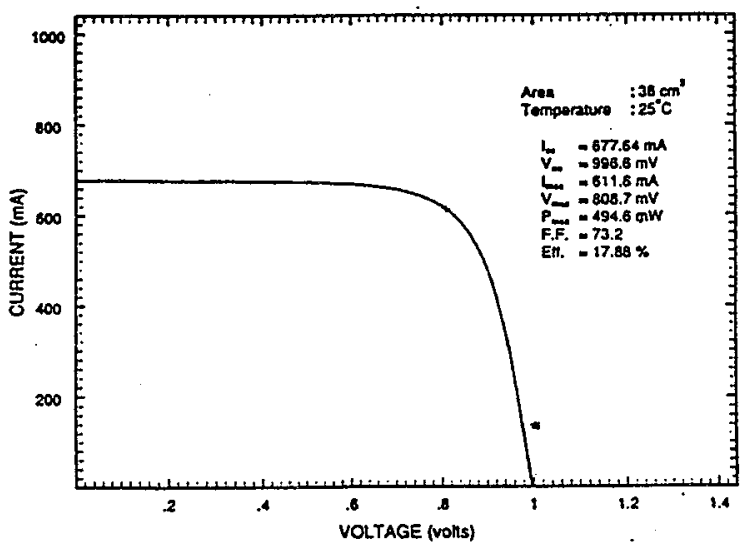

Figure 3: I-V Curve of a Typical GaAs/Ge cell

\section{AIRPLANE DESIGN}

The Solar Electric Airplane being built at NASA LeRC is being assembled much like a model airplane. This is a second generation plane with many modifications for strength and stiffness. It has a dihedral wing, a single fuselage with a pusher prop and twin booms supporting a dual rudder stabilizer. The primary construction material is balsa wood with graphite epoxy sheets and tubes used for reinforcement. The cylindrical fuselage is fabricated from fiberglass. The wing will be skinned using a black mylar Monocote on the underside of the wing, on top a clear Monocote will be applied having an optical transmission of about $93 \%$ above $360 \mathrm{~nm}$. The plane has a wing span of 4.7 meters and a wing cord of 0.31 meters. The span and cord of the tail section are 1.1 and 0.25 meters, respectively. The overall length of the plane is 2 meters with a total mass of approximately 9.2 kilograms. The wing divides into three sections of equal width and locks together using graphite rods. A schematic of the airplane is shown in Figure 4.

The plane will be remotely controlled by a Futaba radio controller with five channels, four are used for servos and the fifth is for the motor. The range of the controller is limited to line-of-sight up to 1 mile. The plane is propelled by a 24 VDC motor which will operate at between 80 and 120 watts supplied by the solar array. A limited number of $\mathrm{Ni}$-Cad batteries will be used to supplement the power during high banks and shadowing. Currently the plane is flying under battery power, when the array is installed, most of the batteries will be removed. 

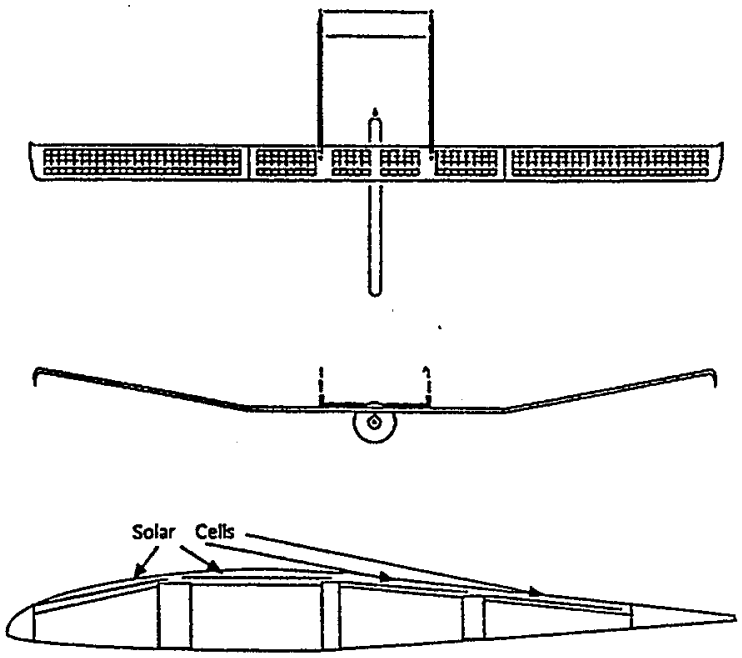

Figure 4: Solar Electric Airplane

The solar array consists of $264 \mathrm{GaAs} / \mathrm{Ge}$ cells 6.0 by $6.0 \mathrm{~cm}$. in area and 3.5 to 4.5 mils thick. The array is divided into 12 strings of 22 cells, each string running a third the length of the wing. Each cell occupies a bay defined by the grid of the spars and ribs, covering the entire wing. A cross section of the wing through the spars is also shown in figure 4. The cells are interconnected using .040" $\times .002^{\prime \prime}$ gold ribbon fastened to the cells by parallel gap welding. Three sets of contacts are used for redundancy and to minimize series resistance. Any repairs to the array will be done using soldering. Each cell will be mounted on $8.25^{\prime \prime}$ diameter closed cell foam pads which in turn are glued to the thin balsa wood sheeting covering the wings. The 8 strings will be connected to a power management and distribution (PMAD) system and isolated using blocking diodes mounted on the underside of the wings between strings. Use of bypass diodes is not presently planned unless future testing reveals a necessity for them.

The cells will be welded together in groups of eleven. Gold ribbon will be welded to the three front contacts of each cell. The cells with their ribbons will be placed face down on a vacuum plate with proper spacing. The ribbons will then be welded to the backside of each adjacent cell making a complete 11 cell series string. With the vacuum on, the plate will be held upside down over the wing section where the foam pads are already bonded in place and coated with DC93-500 adhesive. The vacuum is then released and the cells are lowered into place on the wing. At this time the cells are aligned and the adhesive is cured. The adjacent strings are connected using soldering. Balsa caps are bonded to the ribs and the Monocote is applied. Once the Monocote is stretched over the wing, a heat gun and adhesive is used to shrink it so that it conforms to the wing shape.

Under ideal conditions, the output of the array at ground level will be around 120 watts. The nominal operating temperature of the cells is difficult to predict but preliminary measurements indicate that it should not exceed $45^{\circ} \mathrm{C}$. The aircraft design indicates a stall speed of $15 \mathrm{mph}$ and a cruise speed of approximately $25 \mathrm{mph}$ requiring a minimum power of 83.4 watts. On a typical sunny summer day in Cleveland, Ohio, the plane should be able to fly for 8 hours.

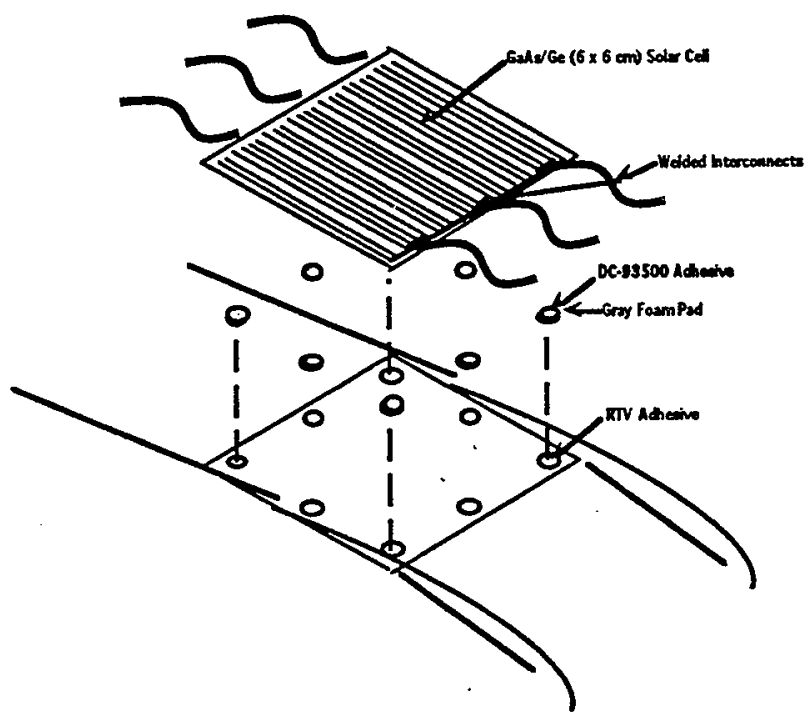

Figure 5: Cell to Wing Assembly

\section{PROTOTYPE WING SECTION}

A short wing section consisting of 5 ribs was constructed and is shown in figure 6 . This was built to test and refine the assembly method and integrity between the cell and wing. The wing section was built using mechanical reject cells. Two rows of five cells in parallel were interconnected and mounted on the wing section by the techniques described previously. This array was measured using Spectrolab LAPSS100 FLASH test equipment both before and after a skin was applied to the wing. The performance of the wing section under AMO illumination is shown below.

$\begin{array}{ll}\text { Isc }_{\text {sc before Monocote: }} & 1029.4 \mathrm{~mA} \\ \text { Isc after Monocote: } & 939.6 \mathrm{~mA} \\ \text { Transmission : } & 91.2 \%\end{array}$

This wing section was also used to demonstrate repair techniques, several cells were removed from the wing and new cells were installed and reconnected using soldering. it will also be used for shock and durability tests. 


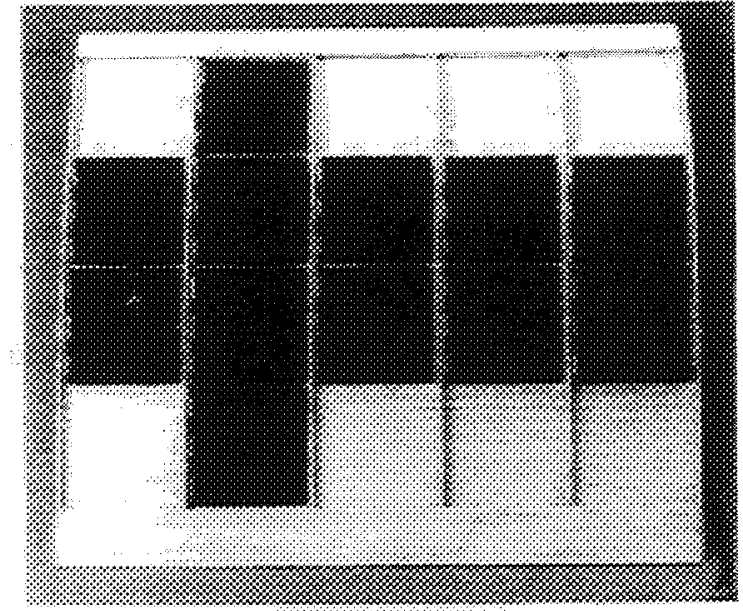

Figure 6: Prototype Wing Section

\section{FUTURE PLANS}

The airplane has been completed and has now flown for seven flights under battery power with no problems (see figure 7). The first prototype plane was damaged due to radio interference and excessive wing flutter. Testing is underway to calculate lift over drag to determine the glide slope. Once the testing is completed, the plane will be populated with a single string of cells and flown to test the cell mounting and interconnect scheme. After a successful flight with no damage to the cells, the plane will be unskinned and fully populated with cells. Subsequent flights will gradually increase in duration and under full solar power with battery assist.

This plane was built primarily for technology demonstration using high efficiency GaAs/Ge cells. It will be flown in an attempt to break a flight duration record for solar powered aircraft. Future plans also include using this plane as a testbed for for rechargeable lithium batteries. When all testing is completed, the aircraft will be turned over to the Air Force ManTech Office.

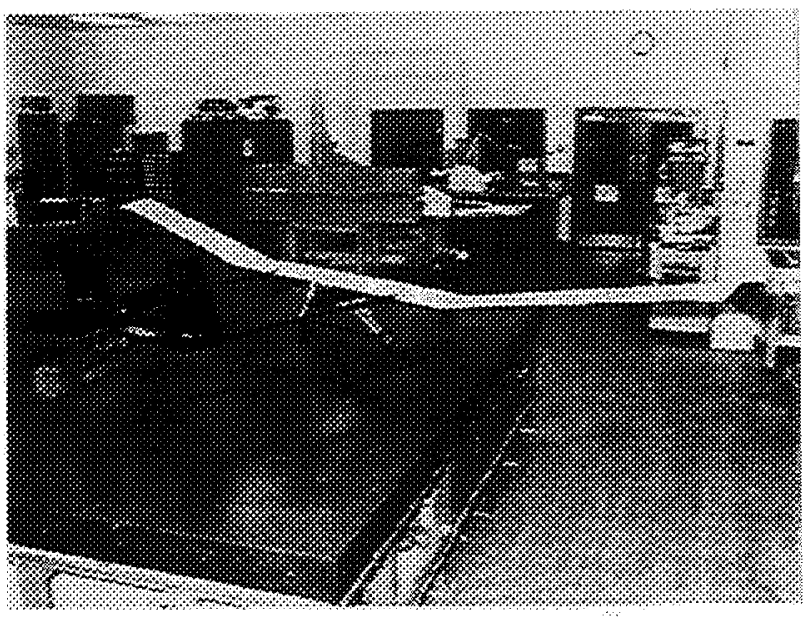

Figure 7: Completed Airplane Under Test

\section{REFERENCES}

[1] William B. Scott, "Cuts Endanger Airborne Research", Aviation Week and Space Technology, May 9, 1994, p. 28

[2] Chenming Hu and Richard M. White, "Solar Cells, From Basic to Advanced Systems", McGraw-Hill Book Company, 1983, pp. 20-21

[3] Y.C.M Yeh, C. Cheng, F. Ho, and H.I. Yoo, "Large Scale, High Efficiency GaAs/Ge Cell Production", TwentyFirst IEEE PVSC, 1990, pp. 79-83.

[4] P.A. lles, H.I. Yoo, C. Chu, J. Krogen, and K-I Chang, "Reverse I-V Characteristics of GaAs Cells", Twenty-First IEEE PVSC, 1990, pp. 448-454. 



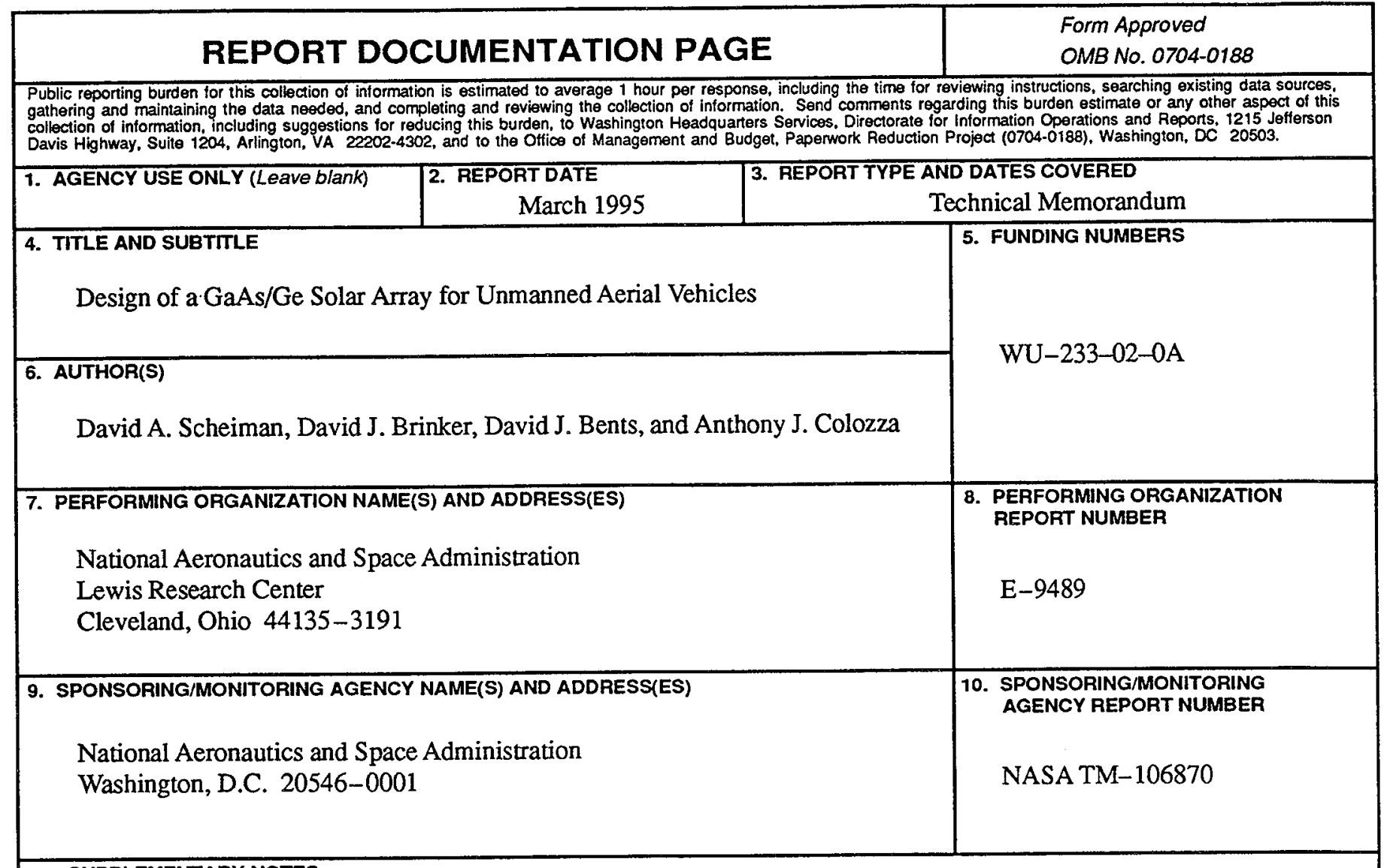

11. SUPPLEMENTARY NOTES

Prepared for the First World Conference on Photovoltaic Energy Conversion cosponsored by IEEE, PVSEC-Japan, and PVSEC-Europe, Waikoloa, Hawaii, December 5-9, 1994. David A. Scheiman and Anthony J. Colozza, NYMA, Inc., 2001 Aerospace Parkway, Brook Park, Ohio 44142 (work funded by NASA Contract NAS3-27186); David J. Brinker and David J. Bents, NASA Lewis Research Center. Responsįble person, David J. Brinker, organization code 5410, (216) 433-2236.

\begin{tabular}{l|l} 
12a. DISTRIBUTION/AVAILABILTY STATEMENT & 12b. DISTRIBUTION CODE
\end{tabular}

Unclassified - Unlimited

Subject Category 44

This publication is available from the NASA Center for Aerospace Information, (301) 621-0390.

13. ABSTRACT (Maximum 200 words)

Unmanned Aerial Vehicles (UAV) are being proposed for many applications including surveillance, mapping and atmospheric studies. These applications require a lightweight, low speed, medium to long duration airplane. Due to the weight, speed, and altitude constraints imposed on such aircraft, solar array generated electric power is a viable alternative to air-breathing engines. Development of such aircraft is currently being funded under the Environmental Research Aircraft and Sensor Technology (ERAST) program. NASA Lewis Research Center (LeRC) is currently building a Solar Electric Airplane to demonstrate UAV technology. This aircraft utilizes high efficiency Applied Solar Energy Corporation (ASEC) GaAs/Ge space solar cells. The cells have been provided by the Air Force through the ManTech Office. Expected completion of the plane is early 1995 , with the airplane currently undergoing flight testing using battery power.

\begin{tabular}{|c|c|c|}
\hline \multicolumn{3}{|c|}{$\begin{array}{l}\text { 14. SUBJECT TERMS } \\
\text { Unmanned aerial vehicle; Solar cells; GaAs/Ge; Airplanes }\end{array}$} \\
\hline $\begin{array}{l}\text { 17. SECURTY CLASSIFICATION } \\
\text { OF REPORT } \\
\text { Unclassified }\end{array}$ & $\begin{array}{l}\text { 18. SECURITY CLASSIFICATION } \\
\text { OF THIS PAGE } \\
\text { Unclassified }\end{array}$ & $\begin{array}{l}\text { 19. SECURITY CLASSIFICATION } \\
\text { OF ABSTRACT } \\
\text { Unclassified }\end{array}$ \\
\hline
\end{tabular}


in 